臨床 移植後の再発性IgA腎症にde novoの膜性

腎症を合併した 1 例

\begin{tabular}{|c|c|c|c|c|c|}
\hline \multicolumn{5}{|c|}{ 金沢医科大学腎藏内科 } & \\
\hline 由利 & 健久○ & 立石 & 圭太 & 杉下 & 尚康 \\
\hline 福田 & 喜裕 & 谷 & 吉雄 & 栗原 & \\
\hline 北田 & 博久 & 石川 & 勲 & 篠田 & \\
\hline
\end{tabular}

\title{
A CASE OF RECURRENT IGA NEPHROPATHY COMPLICATED WITH DE NOVO MEMBRANOUS NEPHROPATHY IN THE GRAFT
}

Takehisa YuRI, MD, Keita TATEISHI, MD, Naoyasu Sugishita, MD, Yoshihiro Fukuda, MD, Yoshio TANI, MD, Satoshi KurIHARA, MD, Hirohisa Kitada, MD, Isao IshiKawa, MD and Akira ShinodA, MD Division of Nephrology, Department of Internal Medicine,

Kanazawa Medical University

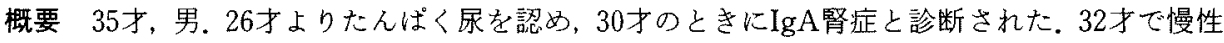
腎不全上なり，4カ月間の血液透析療法後，HLA one haploidenticalの23才の弟より腎葴の移 植を受けた。腎移植後 6 日目に急性拒絶反応があり，pulse療法と血液透析を行ない，腎機能は 安定した。しかし，時々，血尿を認め，術後18カ月目頃上り尿たんぱくも徐々に増加したので， 33力月目に移植腎生検を施行した。光顕では，系球体係蹄壁の軽度の肥厚とメサンギゥム細胞 の軽度の増大がみられた。間質の細胞浸潤はわずかで，血管周囲には、汪とんど認めなからた。 免度蛍光染色では,メサンギウム領域にはIgA C 3 が, 杀球体保餙にはIgGがびまん性に微細顆 粒状に認められた。電䫓でも，系球体基底膜の上皮細胞側とメサンギウムにdense depositを認 めた．IgA腎症は約 $50 \%$ に移植後に再発するとされているが，本例のごとく再発性IgA腎症に， de novoの膜性腎症を合併した報告はきわめて少なく，腎炎の発症機序を考皇る上にも興味あ ると思われたので報告した。
\end{abstract}

\section{緒言}

腎移植後, 移植腎に認められる糸球体病変は, 1）拒絶反応に上る移植糸球体症，2）再発性糸球 体腎炎，3）de novoの糸球体腎炎，4）移植時すで に提供腎に存在していた病変の四つが考えられ る12).どの上うな病変がいつ生じてくるかは，糸 球体腎炎の発症機序を考克るら学に重要と思われ る。われわれは，移植腎に再発性 $\operatorname{IgA}$ 腎症と de novoの膜性腎症の二つの異なる系球体病変が同 時に存在した興味ある1例を経験したので，若干

〔昭和58年11月13日 第121回北陸地方会推䳡〕

の考察を加光て報告する。

\section{症例}

患者： 35 才，男性.

主訴：たんぱく尿，血尿。

家族歴，既往歴：特記するものはない，

現病歴：26才より持続性のたんぱく尿を認 め，28才頃より高血圧を伴い，30才に金沢大学第 一内科入入院して検査を受けた。検尿では尿たん ぱく(十), 尿沈椬でも, 赤血球, 硝子様円柱, 顆 粒円柱があり，血清クレアチニンは，1.8mg/dlで， GFRは $49 \mathrm{ml} /$ 分であつた。腎生検で, 光顕所見は， 中等度のメサンギウム增殖性腎炎で(図 1 ), 免疫 


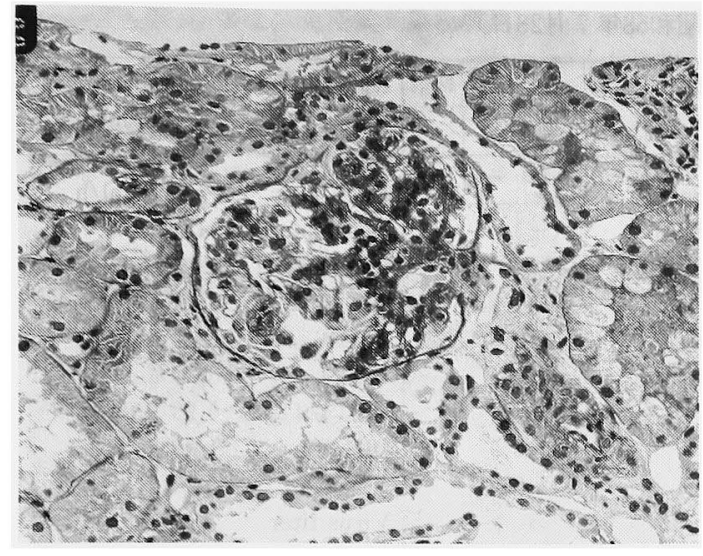

図 1。原疾患の組織像 (血液透析の 2 年前)。中等度の メサンギウム増殖を示す（PAS染色， ×250）。

蛍光染色ではIgA (H), IgG (H), IgM (+), C3 (H), fibrinogen (H)がメサンギウムに認められ, 以後, IgA腎症として治療されていた。しかし，32 才で慢性腎不全となり，血液透析療法が開始され た。血液透析 4 力月後の昭和 55 年 10 月 15 日，金沢 医科大学で，23才の弟より腎蔵の提供を受け，腎 移植がされた，HLAはone haploidenticalでリン パ球混合培養試験のstimulation indexは2.1倍で あつた。腎移植後 6 日目に急性拒絶反応のため pulse療法と血液透析を行なつたが，その後は azathioprine $100 \mathrm{mg} /$ 日, methylprednisolone 8 mgの隔日投与で, 腎機能は安定していた.しかし， 移植後18力月目頃より, 尿たんぱくが増加し, 血 尿も持続するようになつたため，33力月目に移植 腎の生検を施行した（図 2 ).

生検時の検査成績(表 1)：検尿では尿たんぱ くは (\#), 沈椬にて各視野赤血球 24 個, 白血球は 4 個あり，血清総たんぱくは $6.7 \mathrm{~g} / \mathrm{dl}$, 血清クレア チニンは $2.1 \mathrm{mg} / \mathrm{dl}$, コレステロール $218 \mathrm{mg} / \mathrm{dl}$, IgG $1007 \mathrm{mg} / \mathrm{dl}, \operatorname{IgA} 196 \mathrm{mg} / \mathrm{dl}, \operatorname{IgM} 454 \mathrm{mg} / \mathrm{dl}$, C3 $67 \mathrm{mg} / \mathrm{dl}$ であつた。

組織所見：光顕では糸球体係蹄の軽度の肥厚 とメサンギゥム細胞の軽度の増殖が認められた。 しかし，細胞浸潤は，間質にはわずかに認められ たものの,血管周囲にはほとんどなかつた(図 3 )。 免疫蛍光染色では, IgA とfibrinogonは著明にC3 は軽度にメサンギウム領域にのみ沈着しており （図 4 ）, IgGは糸球体血管倸蹄にのみ，びをん性に 微細顆粒状に沈着していた（図 5 ). IgM, C1q, C4 は沈着していなかつた(表 2 )。電顕では糸球体基 底膜上皮細胞側にdense depositがびをん性に認 められ（図 6 ), メサンギウム領域にも dense

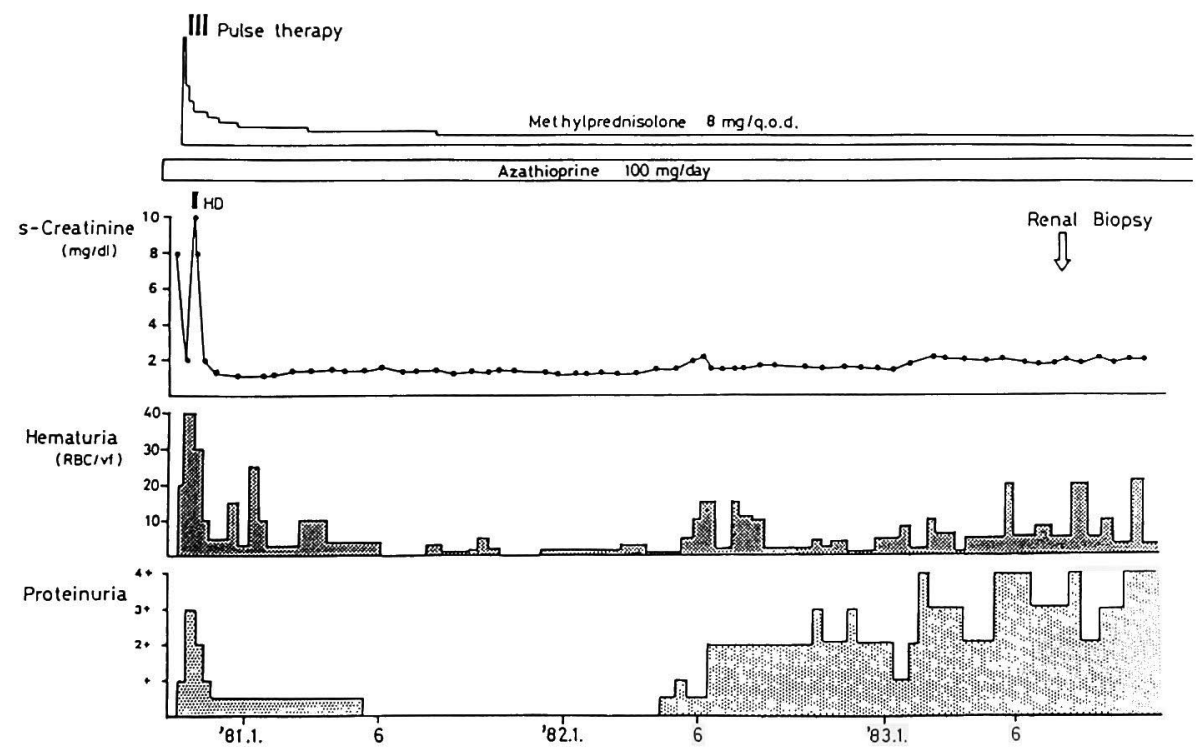

図 2, 臨床経過 
表 1。腎生検時検査成績 (昭和58年 7 月 28日)

\begin{tabular}{|c|c|c|c|c|c|c|c|}
\hline \multicolumn{2}{|l|}{ Urinalysis } & $\mathrm{Na}$ & $143 \mathrm{mEq} / l$ & CRP & $(-)$ & RPF & $218 \mathrm{ml} / \mathrm{min}$ \\
\hline Protein & (m) & $\mathrm{K}$ & $3.1 \mathrm{mEq} / l$ & $\mathrm{RA}$ & $(-)$ & RBF & $387 \mathrm{ml} / \mathrm{min}$ \\
\hline glucose & $(-)$ & $\mathrm{Cl}$ & $101 \mathrm{mEq} / \mathrm{l}$ & ASLO & $(-)$ & GFR & $44 \mathrm{ml} / \mathrm{min}$ \\
\hline sediment & & $\mathrm{Ca}$ & $8.9 \mathrm{mg} / \mathrm{dl}$ & $\mathrm{HBsAg}$ & $(-)$ & PRA & $5.6 \mathrm{ng} / \mathrm{ml} / \mathrm{h}$ \\
\hline $\mathrm{RBC}$ & $23-25 \mathrm{vf}$ & $P$ & $3.5 \mathrm{mg} / \mathrm{dl}$ & $\mathrm{HBsAb}$ & $(-)$ & p-Aldosterone & $177 \mathrm{pg} / \mathrm{ml}$ \\
\hline WBC & $3-5 / \mathrm{vf}$ & Creatinine & $2.1 \mathrm{mg} / \mathrm{dl}$ & & & & \\
\hline hyaline cast & $1 / 3 \mathrm{vf}$ & BUN & $26 \mathrm{mg} / \mathrm{dl}$ & TSP & $6.7 \mathrm{~g} / \mathrm{dl}$ & OKT3 & $35.1 \%$ \\
\hline granular cast & $(-)$ & Uric Acid & $7.4 \mathrm{mg} / \mathrm{dl}$ & Alb. & $59.4 \%$ & OKT4 & $39.5 \%$ \\
\hline & & Cholesterol & $218 \mathrm{mg} / \mathrm{dl}$ & Glb. & $3.0 \%$ & OKT8 & $39.9 \%$ \\
\hline $\mathrm{RBC}$ & $4.65 \times 10^{6}$ & Glucose & $98 \mathrm{mg} / \mathrm{dl}$ & $\alpha_{2}$ & $10.0 \%$ & $\mathrm{OKT} 4 / \mathrm{T} 8$ & 0.99 \\
\hline Hct. & $43.5 \%$ & & & $\beta$ & $11.6 \%$ & OKIAl & $19 \%$ \\
\hline $\mathrm{Hb}$. & $14.2 \mathrm{~g} / \mathrm{dl}$ & GOT & $11 \mathrm{U} / l$ & $\gamma$ & $15.8 \%$ & & \\
\hline Plats & $210 \times 10^{3}$ & GPT & $16 \mathrm{U} / l$ & & & Virus titer & \\
\hline WBC & $7.48 \times 10^{3}$ & $\gamma \mathrm{GTP}$ & $10 \mathrm{U} / l$ & IgG & $1007 \mathrm{mg} / \mathrm{dl}$ & mycoplasma & $<4$ \\
\hline neutro $71 \%$ & mono $5 \%$ & $\mathrm{LDH}$ & $171 \mathrm{U} / l$ & $\operatorname{Ig} \mathrm{A}$ & $196 \mathrm{mg} / \mathrm{dl}$ & cytomegalo & $<4$ \\
\hline lymph $21 \%$ & eosino $2 \%$ & Al-pase & $52 \mathrm{U} / l$ & $\operatorname{IgM}$ & $454 \mathrm{mg} / \mathrm{dl}$ & herpes simplex & $x \times 64$ \\
\hline baso $\quad 1 \%$ & & ZTT & $4.6 \mathrm{U}$ & $\mathrm{C} 3$ & $67 \mathrm{mg} / \mathrm{dl}$ & herpes zoster & $<4$ \\
\hline $15(\mathrm{~h})$ & 43 (2hs) & TTT & $4.6 \mathrm{U}$ & $\mathrm{C} 4$ & $35 \mathrm{mg} / \mathrm{dl}$ & adeno & $<4$ \\
\hline
\end{tabular}

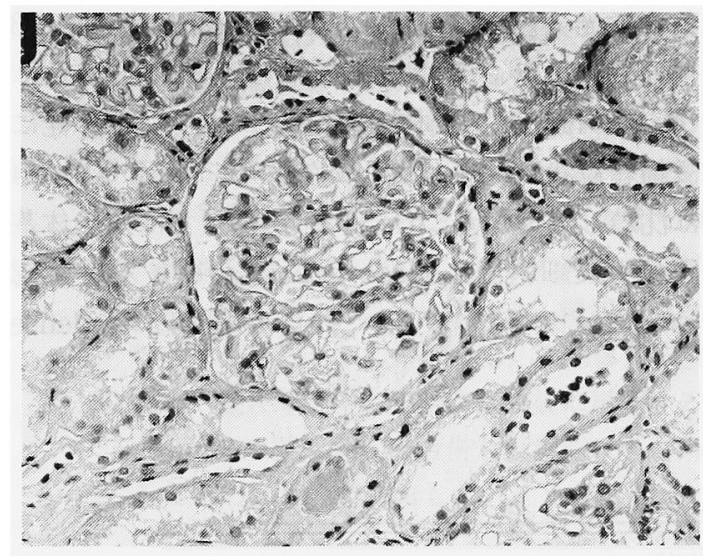

図 3. 移植後33力月目の腎生検像. 系球体係蹄の軽度 の肥厚とメサンギウムの増大がある（HE, $\times 250 ）$.

depositが認められた（図 7 ).

\section{考案}

移植時，提供腎の生検は施行されていないもの の，本例は腎不全に至つた原疾患がIgA腎症であ り、移植後33カ月目の移植腎生検では, IgAがメサ ンギウムに沈着していたので, IgA腎症の再発に よるものと考えられる。

IgA腎症に腎移植した時の再発例の発症につい

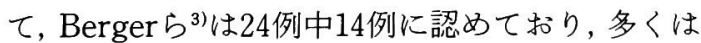
血尿を伴つていた. Cameron ${ }^{4} の$ 文献も加光ての

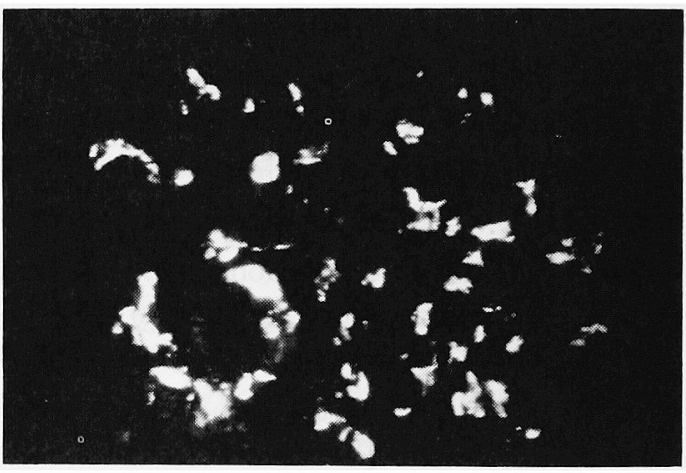

図 4.免疫蛍光染色所見. IgAはメサンギゥム領域に のみ沈着している $(\times 400)$.

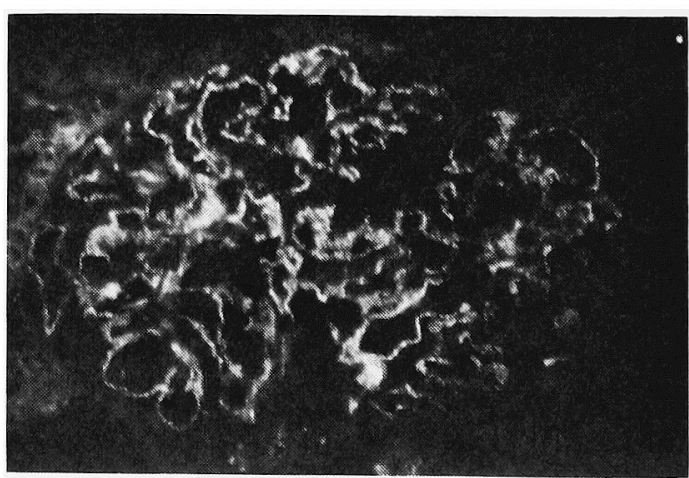

図 5 ，免疫蛍光染色所見. IgGは系球体保啼にのみ, び まん性で微細顆粒状に沈着している $(\times 400)$. 
表 2 . 免疫蛍光染色所見

\begin{tabular}{c|c|c|c|c|c|c|c}
\hline \multicolumn{1}{c|}{ 沈着部位 } & $\operatorname{IgG}$ & $\operatorname{IgA}$ & $\operatorname{IgM}$ & $\mathrm{C}_{1} \mathrm{q}$ & $\mathrm{C}_{4}$ & $\mathrm{C}_{3}$ & $\mathrm{Fib}$ \\
\hline 釆球体血管係踥 & + & - & - & - & - & - & - \\
\hline メサンギウム領域 & - & + & - & - & - & + & + \\
\hline
\end{tabular}

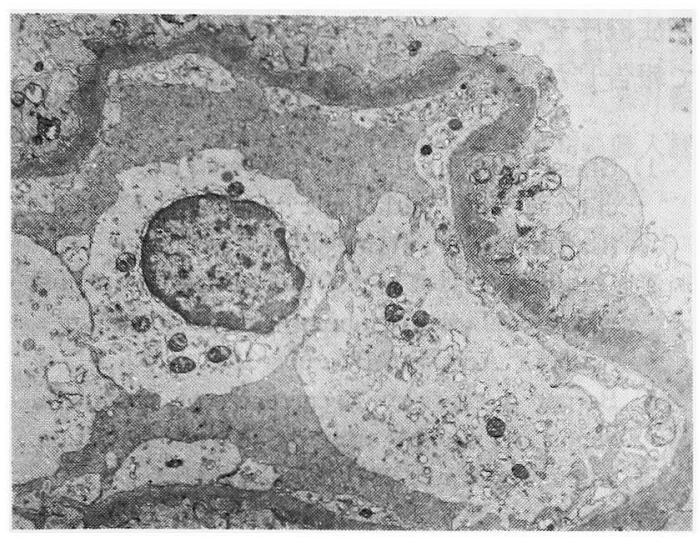

図 6. 電子顕微鏡所見. 系球体基低膜の上皮細胞側に dense depositを認める $(\times 4000)$.

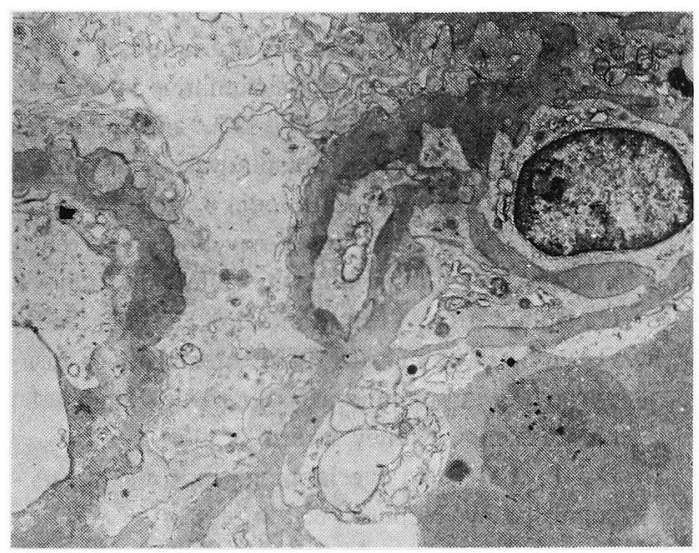

図 7. 電子顕钽鏡所見.メサンギウム領域にもdense depositを認める $(\times 3000)$.

集計では34例の $\operatorname{IgA}$ 腎症に腎移植がなされ，その らちの $53 \% に I g A$ 腎症が再発した。しかし, graft lossに陷いつたのは 3\%であつた。われわれの昭 和 50 年 3 月から昭和 58 年 9 月までの 70 例の生体腎 移植症例では, 再発性腎炎と思われる症例は, 本 例も含めて 3 例あり，他の 2 例もいずれも IgA腎 症であつた ${ }^{5)}$.その 1 例は 30 才の男, 他の 1 例は 25 才の男で，いずれも原疾患について免疫蛍光染色
での検索はなされていなかつたが，それぞれ，移 植後 2 年目と 1 年目に上気道感染後に血尿とたん ぱく尿が持続したので移植腎生検をしたところ， IgAのメサンギゥムへの沈着が認められた。また, 他の 1 例では, IgA腎症で腎不全になつた29才の 男に, 父親の腎臓を移植し， 1 時間後の生検で入 サンギウムにIgAの沈着をみた。これは, 恐らく提 供腎がIgA腎症であつたと思われる。腎移植 1 年 後に慢性拒絶反応で生検したときには, IgAメサ ンギゥムの沈着は消失していた。 Cameron ${ }^{4}$ 名提 供腎にIgA腎症があつた症例では 2 週間から数カ 月でIgAの沈着は消失するとしている.

本邦では, 原発性采球体腎炎の中の約半数が IgA腎症であり，その 5 - 20\%が腎不全に至ると されている.今後, 腎移植例の増加とともに, $\operatorname{IgA}$ 腎症の再発例も増加すると思われる。

本症例でとくに興味深い点は, IgA腎症と同時 に膜性腎症が合併していたことにある、移植腎の de novoの腎炎としては, 膜性腎症が最も多く， Charpentier ${ }^{6}$ )は，1550の腎移植で1000の腎生検 が行なわれ，19例のde novoの膜性腎症を認めて おり,その発症まで平均は1.9年間であつたとして いる. Berger ら Cosyns $ら^{8}$ は851例の腎移植で 9 例のde novoの膜 性腎症が発症したと報告している。本例の原疾患 はIgA腎症であり, 移植後 1 年 6 力月目より徐々 に尿たんぱくが加わつたことより，この膜性腎症 はde novoの腎炎と思われる。しかし，同一個体の 二つの腎症の抗原には，なんらかの関係がある可 能性も考克られる。

非腎移植症例では, Doiら ${ }^{9}$ が報告したメサンギ ウムの IgA沈着と上皮細胞下の $\operatorname{IgG}$ 沈着が同時 に認められた 3 例が，原発性系球体腎炎では最初 の報告であるとしている，移植腎については本例 と同様な $\operatorname{IgA}$ 腎症再発例にde novoの膜性腎症の 発生は, Charpentierら ${ }^{6)}$ の報告にみられる.

本例では，血尿は初めの頃より時々認められて 抢り，尿たんぱくが徐々に増加してきたのは18力 月目で，今後はネフローゼ症候群を呈するおそれ がある．IgA腎症もネフローゼ症候群を呈しらる 
が，膜性腎症の方が高頻度にネフローゼ症候群を 呈するので, de novoの膜性腎症は, 再発性IgA腎 症のあとに発症した可能性が強いが，経時的な組 織学的検索がなされていないので断定はできな い.

本例で尿たんぱくは徐々に増加し，血烁も持続 しているにもかかわらず，腎機能が比較的保たれ ているのは，組織学的に糸球体に半月体や間質， 血管周囲の拒絶反応を思わせる細胞浸潤も認めら れないためと考えられる。おた，再発性のIgA腎症 の予後は良好でgraft lossの原因となることも少 ないとされているが，腎移植後の膜性腎症の予後 は不良となることが多いとする報告が多い.Veraniら ${ }^{10}$ は，腎移植後のde novoの膜性腎症15例, 再発性 7 例の予後について，7例は拒絶反応，腎 機能低下は 1 例, graft lossは 2 例であつたと報告 している。さらにCosynsら ${ }^{8)}$ のde novoの膜性腎症 9 例は, 一度ネフローゼ症候群を呈すると, 腎機 能は徐々に低下し， 5 例は短期間で血液透析にも どつたとしており, 特発性の膜性腎症の予後が比 較的よいのと著しくおもむきを異にしているの は，系球体や間質に慢性拒絶反応の変化が加わる からであるとしている. Bergerらつは，6例のde novoの膜性腎症を報告しており，そのうち 5 例は 診断がなされたあと，副腎皮質ホルモンの投与量 を増加したが，腎機能も尿たんばく量も改善しな かつたとしている，われわれの症例も尿たんぱく が増加し，ネフローゼ症候群を呈する可能性が強 まつており，腎機能の低下をきたす扔それがある 5.

\section{結 語}

IgA腎症で慢性腎不全となり，血液透析療法 4 カ月間行なつたあとに腎移植を受けたが，移植後
33力月目の腎生検で, IgA腎症と膜性腎症が同時 に認められた症例を報告した。腎移植後のIgA腎 症の再発は約53\%に起こり, de novoの堅炎とし て膜性腎症は最も発症し易いものとされている が，両方の合併についての報告は少なく，腎炎の 発症機序を考古るらえにも興味あると思われるの で報告した。

\section{文献}

1) Glassock RJ, et al : Human renal isografts: A clinical and pathologic analysis. Medicine (Baltimore) $47: 411,1968$.

2) Hamburger $J$, et al: Observations in patients with a well tolerated homotransplanted kidney. Ann NY Acad Sci 120 : 558, 1964.

3) Berger $J$, et al: Recurrence of mesangial deposition of IgA after renal transplantation. Kidney Intern 7: 232, 1975.

4) Cameron JS: Glomerulonephritis in renal transplants. Transplantation $34: 237,1982$.

5）篠田 晤，他：移植腎に㧍ける系球体病変。日医 大誌 $50 ： 890,1983$

6) Charpentier B, et al: Etude cooperative des glomerulonéphrites extra-membranouses "de novo" sur allograffe rénale humaune; rapport de 19 nouveaux cas sur 1550 transplantes renaux du groupe de transplantation de I'Isle de France (GCIF). Nephrologie $3:$ 158, 1983.

7) Berger $\mathrm{BE}$, et al: De novo and recurrent membranous glomerulopathy following kidney transplantation. Transplantation 35:315, 1983.

8) Cosyns J-P, et al: De novo membranous nephropathy in human renal allografts : Report of nine patients. Kidney Intern $22: 177,1982$.

9) Doi T, et al: An overlapping syndrome of IgA nephropathy. Nephron $35: 24,1983$.

10) Verani RR, et al: Membranous glomerulonephritis in renal transplant. Amer J Nephrol 2: 316, 1982. 